\title{
Parliamentary Immunity among Arab Constitutions
}

\author{
Jehan K Samarah Alzubi ${ }^{1}$ \\ ${ }^{1}$ ALBalqa Applied University, Jordan \\ Correspondence: Jehan K Samarah Alzubi, ALBalqa Applied University, Jordan. E-mail: \\ jehan.alzubi@bau.edu.jo
}

Received: February 9, 2020

Accepted: March 1, $2020 \quad$ Online Published: May 30, 2020

doi:10.5539/jpl.v13n2p269

URL: https://doi.org/10.5539/jpl.v13n2p269

\begin{abstract}
Point of fact, legislature is seen to be a significant body in any country because of its key duties of passing the legislations regarding the responsibility it has. The national and legal system has given legal protections for the legislature' members in order to help them in carrying out the responsibility they have according to the countries' constitutions, and this kind of protection is known to be the parliament immunity. The present study aims to clarify the parliamentary immunity concept explaining its own legal nature among Arab constitutions. Additionally, this study discusses important points related to the parliament immunity such as its types, namely, objective type as well as procedural type differentiating between them. Furthermore, this study indicates to some important aspects regarding parliament immunity among Arabs highlighting points like the lifting procedures of the immunity and some legal reasons for lifting and the constitutions' positions regarding that. The study concludes that Arab countries have a special situation due to important events such as Arab Spring and Palestinian Issue in which they confirm that the Arab countries must deal with the parliament immunity carefully in a way that makes their people satisfied, lastly, some recommendations are made for further studies in the same topic.
\end{abstract}

Keywords: parliament immunity, Arab countries, constitutions, parliament members

\section{Introduction}

Point of fact, throughout history of parliaments, they have been known as the people's voice as the parliaments' main purposes are to represent the nation entirety in countries. Additionally, the members' main roles of parliament do not only mean to represent people regarding their own provinces, however, they have greater roles in which they represent the entire nation of the country. The constitution of the country has assigned the parliament as well the duties of the parliament as it watches over the activities of the government and passes the country's legislations. It also provides a balance for both the executive and legislative authorities to enable them practice their constitutional duties in the country. For the creation of such balance, the parliamentary immunity plays the main tool to achieve this. Parliamentary immunity, the parliament members as well as the senate discuss the decisions that will be made by the country government regarding the people's will represented without threats or pressures of questioning or legal actions by the executive government inside the country (Alrfua, Sabah, \& Alrfoua, 2018).

The right of such position for the parliament members has obtained its power all over the world by the constitutions in order to confirm that the members of parliament cannot confront any legal pressures that are set to strong-arm these members into any party' submission and provides the members with the freedom of choice as well as the freedom of expression. Having a parliamentary immunity does not mean at all that this parliament member is a legislature member and he/she is above the law, however, it is only a tool that protects these members since they serve the duties of constitution (Alrfua et al., 2018). One of the most significant tools of the constitution is the parliamentary immunity as it organizes the relationships of the following three powers, namely, the legislative, juridical, and executive authorities; it is a prominent and significant element in framing the present relationship picture between the above-mentioned authorities (Alaazmi, 2011).

The present research study has its significance as it sheds lights on the parliamentary immunity justifications and the legal implications among Arab constitutions in which they help in protecting the legislature members from the malicious and intimidation legal prosecutions caused by executive governments. In addition, this research aims to see why the parliament immunity is deemed to be significant. Furthermore, the present study targets to 
weigh the legal immunity's weaknesses and strengths in order to illustrate general perceptions to provide with a relevant feedback to the decision-makers regarding the legislative bureau and parliament.

The main reason of such study is thru the observations obtained from the parliamentary councils due the differences between Arab ruling countries systems as they have kingdoms, republics, emirates, and Sultanate. Besides, it is noticed that some problems appears regarding the parliament immunity. E.g., In Jordan, (Alrfua et al., 2018) mentioned that

"it was necessary to have a study discusses reasoning behind revoking or keeping the immunity instated in light of the offences the member of parliament might have committed, and so parliamentary immunity which constitutions have guaranteed, is only to protect freedom of opinion and expression and the freedom to practice their duties with complete independence and without fear of being intimidated by the executive government" (p.72).

The parliamentary immunity doctrine had been already existed during Roman Empire. It was prohibited, at that time, to attack the representatives of Roman people or interfere in their functions' exercise (Van der Hulst, 2000). Regarding the parliamentary immunity as an issue, Wigley (2003) investigated a study to see does the parliamentary immunity system protect the democracy or protect the corruption? Such highlighted issues indicate that investigating the parliament immunity is a significant topic and it should receive more attention. Therefore, the present study attempts to discuss the following points: firstly, the parliamentary immunity concept, next, the parliamentary immunity's justifications and forms.

\section{The Parliamentary Immunity Concept}

The immunity is defined as it is a privilege decided and provided by internal law of a country or the international law in which it relieves a person from an imposed burden on the individuals of specific nations in general or it grants her/him this privilege not to be prosecuted by any legal authority. The parliamentary immunity's historical foundation returns to the year 1397 when the House of Commons in the United Kingdom's parliament had voted on a law in which this law condemns the King Ritchard the second which had consequently led to prosecute Thomas Haksy as he is a parliament member regarding the issue with the execution due to his betrayal. Consequently, the royal pardon had been released because of some arguments by some groups which had been taken to the House of Commons in order to discuss the members' rights of this house to freely talk without any interruption caused by the royal court. Also, this is known as the parliament members' rights, in the $16^{\text {th }}$ century, to express their opinions and this had been deep-rooted it, through the rights presented in the law in 1689, in the $18^{\text {th }}$ century. This kind of agreement grants the members the right to do, discuss, and talk in the parliaments and these participations do not cause a legal prosecution in any legal courts. As for the issues that are associated to major crimes, betrayal, and disturb the country's security, they are all exempted from the parliament immunity, so it was possible to attest any of the parliament members in any of these crimes with being disclosed from immunity (Hussainyeh, as cited in Alrfua et al., 2018).

Parliament immunity has some categories: substantive immunity and procedural immunity. Firstly, substantive immunity is seen to be a parliament member who cannot be held responsibility legally for his suggestions as well opinions in parliaments. Secondly, procedural immunity is known as not having a legal action to be taken against the parliament member by any citizens or parties when they are members into their parliamentary terms unless there is a permission given by parliamentary councils, except when there is a case that these members commit any offence against other members during the term of the parliamentary (Alrfua et al., 2018; Altugeeri, 2009).

According to Kashakesh (2007) in the some jurists' opinion, the procedural immunity is also seen as a privilege granted by a constitution and given to a parliament member not for a personal reason but due to their role as a representative because they represent people, so these members might practice the duties they have according to their abilities. Even though the parliament immunity is guaranteed by a constitution, this immunity does not pardon the members who have any offences; any crime found is being postponed unless the members are caught in a blazing offence. Immunity system is deemed to protect a parliament member against claims of civil and penal offence (Jain, 1984). Accordingly, it is clear that the key aim of the parliamentary immunity is ensuring that a parliament member cannot be suddenly extracted from councils during the term they are in, only if it is obvious to the council of the parliamentary that the offence has, is actually committed as well it is not a malicious claim whose goal is to stopping a parliament member from fulfilling the duties of the members who are representatives, and this could limit the immunity of the parliament.

As the substantive immunity, it is known to be a permanent immunity associated to the speech or ideas presented by the parliament members and they are not questioned in that regard even after the term of the member has been completed. However, procedural immunity is a postponing action's matter, and so it is noticed that there is no 
influence regarding the legislations done by the members committing any offence. If there is any case that a member is caught in blazing offence, this member will be detained without informing the council that they are involved in. For example, in the law in France, where the parliament member is being detained due to an offence waiting a legal action until the council, which this member belongs to, agrees allowing them to launch, and before the term of the council officially launches anyone could pursue a legal matter concerning the members of the parliament. Besides, a difference is seen in the implementing immunity's extent regarding the various offences' types. The extent, in some cases, comprised misdemeanours and crimes as it was shown in the legislations of Egypt (Alrfua et al., 2018).

For preserving the legislative authority independence, it might carry out the duties it has with some kinds of freedoms that are needed for its members to do so, these members should be protected from any malicious allegations, lawsuits, or threats that could interfere with their abilities in performing the duties they should do. In doing so, the parliament immunity could protect the parliament member because their own jobs dictate that necessary, and due to their personal reasons. Consequently, the immunity of parliament members is deemed a significant element of a constitution since it regulates the various government bodies' relationship and it gives the parliament members the freedoms in expressing their ideas and opinions without being questioned so this member can achieve the wills of people that put him/her into the parliament. Hence, this immunity of parliament members is against legal actions or against the liability of the parliament (Alaazmi, 2011). The immunity granted is only an instrument that provides speech freedoms as well as expressions as described by some jurists of being procedural platforms to delaying lawsuits and legal actions with a permission from the council they belong to during her/his term of the parliament and the immunity does not pardon any member from any crimes, responsibilities, or offences that any members might have or commit. The immunity of a parliament is seen to be a general political system part creating a consequential condition (Alaazmi, 2011):

1) Parliament members do not have any options to removing the immunities they have under any conditions.

2) When any case is being sent to the court before ending the term of a parliament; it is obligatory for this or that court to rejecting it and the court attempts to make the rule automatically even though the members do not specifically use the immunity.

3) If the legal criminal procedures are being varied out against a parliament member without having the council permission unless being caught in a blazing offence, it will be deemed null.

4) It is allowed to use immunity system regardless the lawsuit stage is in, though the first time in the courts for a revocation or resumption.

Some might consider the immunity of parliamentary as a way that a member to bypassing constitutions stating that all citizens are equal due to their views they consider this immunity as a way saving them from punishments and consequently, they may implement it to break laws, abuse positions because of personal gains or to commit criminal activities and being unquestioned (Shurun, 2010). On other hands, some individuals suggest that it is not for a protection purpose within parliaments but protecting from the prosecutions during on the term of the parliament (Shurun, 2010). Immunity, in general, is seen to be a principle agreed worldwide by the majority of constitution in spite of the varieties in legal or/and political systems since it protects the independence of the role they play and it is not associated to a personal reasons (Saleh \& Tamah, 2011).

The parliament is formed in order to represent citizens, hence, this parliament has to concern with anything related to the benefits of individuals, that is to say, the parliament should attempt to defending as well as negotiating on their behalf in all matters. Thus, the predominant opinions propose that the immunities of the parliament do not reach the scales of the favor of anyone regarding the equalities between individuals since these equalities are applied to these individuals within a group having the same circumstances and status. Because the parliament could be considered various groups with some circumstances, hence, the parliament immunity is only given to these members due to the conditions that are granted to them by their duties' nature which includes defending the interests of people as well as questioning the decisions of government. This makes immunity system having a protective and transitionary necessity to leave any interference from other parties of the government in the duties they have (Al-Qaisi, 2011).

According to the above discussion, many various views and opinions were highlighted by some studies. These opinions believe that immunity system is an instrument protecting a parliament member to face any trials from crimes and the equality concepts. Some argue that all councils that are elected do not have immunities for their own members. The concept of the immunity system does not influence the equality principle. Anyone could state that it is a job having a privilege within the parliamentary work frame, and here, it is clear that this kind of privilege is not due to personal reasons, they are to protect the roles they have as a parliament member, and 
hence, they can do their own duties without fear caused by other governmental or political parties (Alrfua et al., 2018).

\section{Parliamentary Immunity's Forms and Justifications}

The idea of the parliamentary immunity is being derived from the principle stating that the people of the nation are its authority source, and parliament members are only those people's representatives and hence, when a parliament member raises any voices or issues of an opinion or/and idea, in fact, they echo the people's voice. The immunity idea is introduced in the United Kingdom in the $17^{\text {th }}$ century when immunity was seen to be a privilege granted for the common good and who are in favor of people (Alaazmi, 2011). This immunity, in the United Kingdom, was called as a parliament privilege and it indicates to two main functions, firstly, a member has a freedom to speak and secondly, the ability to challenge the crown (Bomdian, 2015).

It is deduced that parliament immunities do not mean when a member who committed a crime and holding the immunity is protected or legal, but the immunity he/she has, delays an inevitable event and then, any legal procedures will be run and permission will be obtained by the certain conditions' fulfillment or the respective council. However, the substantive immunity has no an expiry date in which it indicates that the members' right to be protected regarding his/her opinions stays though their parliament term has ended (Fawzi, 1994). According to Alshawabkah (1997) it is considered to be a guarantee against legal actions' arbitrary commencement against parliament members that might be malicious; this all since members are opposed in their ideas or opinion towards the policies of government or any member placing a sector of any government under a specific procedures or a scrutiny and this is deemed to be one of the members' right.

Accordingly, the parliament immunity has included two various types, namely, objective parliament immunity and procedural immunity. Firstly, objective parliament immunity is described to mean a parliament member cannot be prosecuted in any civil court or criminal at any time regarding any ideas or opinions (Al-Qaisi, 2011; Alrfua et al., 2018; Murad, 2015). In this regard, Al-Jamal (1995) indicates that the parliament member is able to freely speak within the authorities and present any opinions or ideas without any kind of fear in order to fulfill their own duties as much as they are able to. It is explained by Alaazmi (2011) the objective parliament immunity does not mean to be not absolute; in fact, it is limited by the two following significant elements:

1) Opinions that are presented by a member during their parliament term serving, during legislative sessions, and during voting against or for any legislation, accordingly to their own beliefs regarding any matter, or during any investigating are directed at any government member.

2) Opinions or ideas members expressing outside parliaments, however, they are associated to the opinions or duties that they might express thru their memberships in various committees in councils.

The objective parliament immunities have some features and characteristics specified as follows by Murad (2015).

1) Permanent immunity: in this aspect, it means to protect a parliament member when they serve their parliament term as well as after its end, hence, the parliament member gets some benefits from permanent immunity even though they are not re-elected to present their people, and this is for protecting opinions that are said during the immunity period.

2) Absolute immunity: this aspect of immunity contains the objective immunity in which members are protected from criminals, political and civil liabilities, hence, the office of public prosecutors cannot launch any legal files associated to those areas, and the affected parties are not demanded for any sorts of civil compensations as well political authorities, in any way, cannot prosecute these members.

3) Complete immunity: this aspect of parliament includes all opinions, speeches, and everything is said by members under their duties umbrella.

4) It is seen as parts of general laws/regulations: this means that a parliament member cannot revoke or refuse the immunity they have and the judge should automatically take it into account as it could be invoked at any lawsuit stage.

As for procedural immunity, Murad (2015) mentions that procedural immunity refers to the legal procedures' prohibitions to be commenced against parliament members regarding any crimes until the permission is given from parliamentary councils. In this regard, Jordanian constitution and Palestinian constitution can be taken as examples. In Jordanian constitution, the article " $1 / 86$ " with its amendments dictated says the Parliament or Senate members are not prosecuted or detained during meetings unless there is a decision made by a vast majority saying that justified reasons are highlighted or when a member is detained during criminal offenses and 
in doing so, a council should be immediately informed. The Jordan constitutional court interpreted this text in the decision "7/2013" saying that courts consider that a parliament member has not to be prosecuted or detained during the meeting for any criminal acts after or before they are a member until she/he carries the immunity in which it has to be agreed by the Parliament or Senate's vast majority which they belong to. This indicates that the court of a constitution has broadened the parliament immunity boundaries including criminal acts committed by members having immunity before or after they are being members. A very recent events, in Jordan, occurred with two of the parliament members "Mr. Ghazi Alhawamleh and Mr. Sadah Alhabashneh" in their case "The Jordanian parliament agreed on the judiciary request to refer two former ministers to court on charges of abusing their job jurisdictions, while it refused to waive the immunity of two deputies in two different cases" (Alrawashdeh, December, 2019). As for the constitutional court in Palestine grants, the rights for their president lifting any members in the council of legislation of the immunity without holding the council according an interpretative decision " $3 / 2016$ " in which it has dictated that the high court of constitution considers the decision " $4 / 2012$ " that is taken on " $3 / 1 / 2012$ " implying the lift of immunity for the members of legislative council e.g., Mohammad Dahlan, whom was contested in the court sue to a criminal case, the decision was cancelled "326/2915" making appropriately as well as in accordance to the rights that are given to the president in the law (Alrfua et al., 2018). Additionally, the procedural parliament immunity comprises the physical freedom principle since they might be detained physically and then, they cannot vote against or in favor of certain issues, hence, such prosecutions do not have anything regarding the parliament affairs as everything in parliaments is being protected thru the objective immunity (Alaazmi, 2011).

\section{Immunity System in Arab World}

According to Perthes (2008) there is no a single Arab country from Morocco to Iraq has a consolidated liberal democracy. This claim can be proved by the Arab Spring that has appeared during that time. Seven Arab countries were affected directly from such lack of democracy e.g., Yemen, Egypt, Tunisia, Libya, Iraq, Syria, and Algeria. In addition, some other Arab countries faced some challenges such as Jordan, Morocco, and Bahrain. Lastly, other countries were totally aware from this Spring, so they made some serious changes. This claim by Perthes (2008) is supported by some other researchers who state that prior to the protests' wave which was in the Arab world, some Western theorists had revealed in length about the seeming immunity of Arab countries to democratic changes relating their views mainly to the Arab culture passivity as well as the Islam resistance to the modernization (Achcar 2016; Khneisser, 2019). Bayat (2013) added several Middle Eastern observers had also depicted the Arab world as an exceptional case regarding static continuity, enduring authoritarianism, and cultural passivity.

According to Ballantyne (1985) in Gulf Countries such as Bahrain, Kuwait, the United Arab Emirates, Qatar, the constitutions was written based on the constitution of Egypt, France, the United States and human rights' universal declaration of 1948. Some changes later have appeared regarding the constitutions of these countries. The above-mentioned countries have written their constitutions in the recognizable modern form. As for Saudi Arabia and Oman, they have a Sultan or a king and the council strongly directed by Sharia. The Arab constitutions are different, consequently, their parliament immunity is different e.g., Kuwait and Jordan, it is stated by (Alaazmi, 2011) that the parliament immunity application is seen to be weak and not completely clear. In addition, in Iraq context it is mentioned by (Alkhfagy. 2010) that the parliament immunity is limited due to its period and mentioning the cases of removing the immunity.

\subsection{Arab Constitutions}

According to Sultany (2019) Arab constitutions' scholars described these Arab constitutions as "constitutions without constitutionalism". He explains this term is used since Arab constitutions did not often succeed to impose an effective limit on the executive power exercise, and defending basic rights of people. The Islamic religion is clearly seen in the Arab world constitutions, and this is almost available in all with Muslim majorities, in a various ways (Dupret, 2016; Sultany, 2019). For example, Article 3 of Syria's Constitution states that "The Islam is the religion of the President of the Syrian Republic. Also, Article 74 of the Tunisian "Constitution goes a bit farther, granting to all voters who have held Tunisian nationality since birth the right to run in presidential elections - provided their religion is Islam" (Brown, 2017, p.4).

This shows that Arab constitutions in each country are different from each other. This kind of difference affects the nature of a country constitution. It also indicates that there are many difference are existed in the country policies. Consequently, the parliament immunity is being various among Arab countries as it is associated to each country's constitution. This kind of difference is noticed as the ruling systems are various. These countries have republic, royal, emirates, or sultanate ruling systems. Even though Islam is seen to be existed in Arab 
countries, they use Islam in their policies in different ways.

\section{Conclusion}

It can be clearly noticed that the parliament immunity is seen to be an important factor that parliamentarians should obtain with cautious which means that the parliament members must feel totally free to speak and express their own ideas as they represent people when these members feel safe to speak and express opinions; people will be satisfied with the ruling system, especially, in Arab context as the ruling system is different; some countries are republics, kingdoms, emirates and sultanate. Moreover, the Arab situation is not stable due to the Arab Spring effect and currently, the Israel and Palestine issues of Jerusalem as these issues are related to religion and politics. The most significant point that should be guaranteed that a parliament member freely carries out his/her duties along with the constitution in which these members can criticize the government, direct inquiries and questions as well as using all the means that could be used to supervise the decisions of government.

It is also concluded that the political systems in countries play an important role in determining the nature of the parliament immunity and limiting its own structure and conditions in which it is narrow or wider according to the political system implementations and the countries' constitutions. Additionally, due to the general observation regarding these constitutions allowing the present study to recommend the necessity of limiting the parliament immunity regardless its types and to be limited to the member only. As the concept of parliament immunity does not have one definition and this guides to the varieties of implementing the concept, it is recommended that unifying the concept to be clear among countries as this world becomes a small village. To sum up, this study indicates the parliamentary immunity is seen to be significant in different ways. It plays an important role in the stability of a country. If the members of parliaments do not have the freedom to speak or they are not able to criticize the governments' behaviors as they do not have a parliament immunity allowing them speak freely, this will lead to problems inside the country. In fact, these members do not represent themselves, they represent citizens.

\section{References}

Achcar, G. (2016). Morbid Symptoms: Relapse in the Arab Uprisings. London: Saqi Books.

Alaazmi, M. M. (2011). Parliamentary immunity a comparison between Jordan and Kuwait (Unpublished Master's Thesis). Middle East University, Jordan.

Al-jamal, Y. (1995). Egyptian constitutional system (2nd ed.). Dar alnahda alarabyia, Cairo.

Alkhfagy. A. (2010). Parliament Immunity: an empirical study within the Iraqi constitution of the year 2005 (Unpublished Master's thesis). Alkufa University, Iraq.

Al-Qaisi, H. M. (2011). A comparative study between the internal regulations of the parliamentary council and the national Kurdish council. Almuntaseriah University.

Alrawashdeh, M. K. (December, 2019) Jordan: Parliament Refers 2 Former Ministers to Court, Refuses to Waive Immunity of $\quad M P$. $\quad$ Retrieved from https://aawsat.com/english/home/article/2028201/jordan-parliament-refers-2-former-ministers-court-refuses -waive-immunity-mp

Alrfua, A. Y., Sabah, A. H. A., \& Alrfoua, A. Y. M. (2018). Parliamentary Immunity in International Legislation. Asian Social Science, 14(6). https://doi.org/10.5539/ass.v14n6p71

Alshawabkah, I. (1997). Parliamentary immunity: Comparative study (Master's Thesis). Amman, University of Jordan.

Altugeeri, A. bin A. (2009). Parliamentary immunity and its application on the saudi consultative council (Masters Thesis). Naif University for security sciences, Alriyad.

Ballantyne, W. M. (1985). The Constitutions of the Gulf States 1 a Comparative Study. Arab Law Quarterly, 1(2), 158-176. https://doi.org/10.1163/157302585X00040

Bayat, A. (2013). The Arab Spring and Its Surprises. Development and Change, 44(3), 587-601. https://doi.org/10.1111/dech.12030

Bomdian, A. (2015). Parliament immunity; A comparative study (Published PhD Thesis). Abu Bakr University, Qaid, Telmsan.

Brown, N. J. (2017). Comparing the Religion-State Divide in the Arab World: Constitutions. Policy. 
Dupret, B. (2016). The Reference to the Sharia in Arab Politics and Constitutions. Constitutionalism, Human Rights and Islam after the Arab Spring,

Fawzi, S. (1994). The parliament: An analytical comparative study between world parliaments (1st ed.). Cairo: Alnahda Alarabyia Printing Press.

Jain, M. P. (1984). Parliamentary Privileges and the press. NM. Tripathi private Ltd, Bombay, India.

Kashakesh, K. Y. (2007). Procedural immunity a constitutional guarantee for parliamentary work. AlmanarahJournal, 13(8).

Khneisser, M. (2019). 'Civil Societies' and the Arab Uprisings-prospects for Socio-political Change: A Comparative Analysis of the On-going Tunisian and egyptian plight. In Women, Civil Society and Policy Change in the Arab World (pp. 11-32). Palgrave Macmillan, Cham. https://doi.org/10.1007/978-3-030-02089-7_2

Murad, M. O. (2015). Parliamentary immunity in Palestinian legislations (Unpublished Master's Thesis). Islamic University, Gaza.

Perthes, V. (2008). Is the Arab World immune to democracy? Survival, 50(6), 151-160. https://doi.org/10.1080/00396330802601909

Saleh, A., \& Tamah, N. (2011). Legal system for immunity ( $\mathrm{PhD}$ thesis in general law). School of Law, Algeria University.

Shurun, H. (2010). Parliamentary immunity (5th ed.). Algeria: A published study in Almufaker Journal, School of Law and Political Sciences, Mohammad Khadr University.

Sultany, N. (2019). Arab constitutionalism and the formalism of authoritarian constitutionalism. In Authoritarian Constitutionalism. Edward Elgar Publishing. https://doi.org/10.4337/9781788117852.00018

Van der Hulst, M. (2000). The parliamentary mandate: a global comparative study. Inter-Parliamentary Union.

Wigley, S. (2003). Parliamentary Immunity: Protecting democracy or protecting corruption? Journal of Political Philosophy, 11(1), 23-40. https://doi.org/10.1111/1467-9760.00165

\section{Copyrights}

Copyright for this article is retained by the author(s), with first publication rights granted to the journal.

This is an open-access article distributed under the terms and conditions of the Creative Commons Attribution license (http://creativecommons.org/licenses/by/4.0/). 